\title{
Dirty pigs beat disease
}

\section{污い環境で育った子ブ夕は病気に強い}

\author{
Natasha Gilbert
}

Nature Vol. 462(558)/3 December 2009

污れた子ブタは、のちのち強力な免疫系 を作り上げていくのに役立つ「有益な」 細菌を取り込んでいる、とする研究成果が 得られた。きれいすぎないブタのような生 活は、健康によいのかもしれない。

この成果は、衛生に関するある仮説を 支持する。それは「出生からしばらくの間 に微生物との接触がないと、免疫系の発 達に悪影響が及び、アレルギ一や炎症性 腸疾患のような病気にかかりやすくなるこ とがある」というものだ。

研究を進めているアバディーン大学（英 国）の消化管免疫学者 Denise Kelly によ れば、この結果は、幼年期の微生物との 接触と、免疫の健康や遺伝子発現との間 の直接的な関係を初めて明らかにしたも のだという ${ }^{1}$ 。これまで、こうした関係は 二次的なものとされていた、と Kelly はい う。「腸の微生物䪭、およびそれが免疫機 能と病気やアレルギーへのかかりやすさに

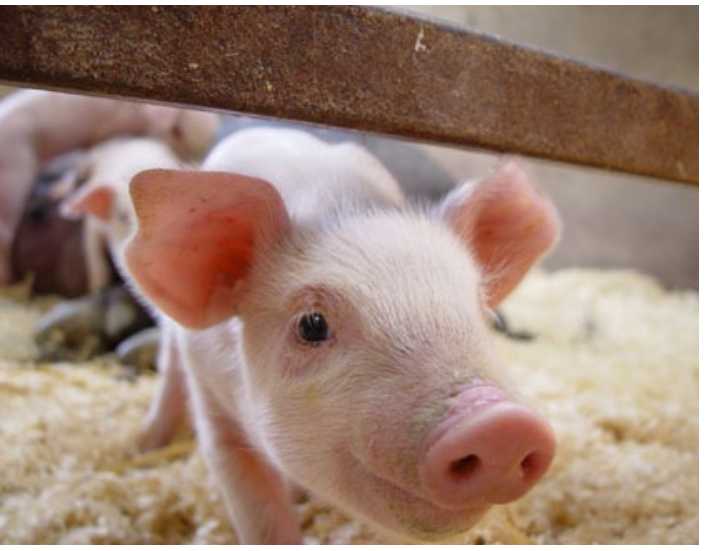

屋外飼育の子ブタには、屋内で飼育された子ブタ よりも「有益な」腸内細菌が多かった。
どのように影響しているのかを巡っては、 さまざまなことがいわれてきました」。

デカルト大学 (フランス・パリ) の免疫 学者 Jean-Francois Bach によれば、この “衛生仮説”は今や多くの研究者に受け 入れられているが、その仕組み、すなわ ち、微生物叢が腸内でどんな役割を果た しているのか、病気から体を守るうえで感 染がどう役立つのかなどに関しては、まだ 謎が残されている。Bach は「生まれた直 後の日々がとても重要だということを、こ の論文は示しています」ともいう。

研究チームは子ブ夕を 54 頭用い、それ を屋外の環境、屋内の環境、それに毎日 抗生物質を投与する隔離条件の 3 集団に 等分して飼育した。子ブタは、 5 日目（新 生児期)、28日目 (離乳期)、56日目（ほ ぼ成熟期）にサンプリングし、腸組織と筫 を分析した。

その結果、屋外飼育の子ブタの腸にみ られた細菌の 90 パーセントが、ファーミ キューテス門のものであることがわかっ た。その多くは「乳酸桿菌科」の細菌で、 これらは大腸菌やサルモネラ菌などの腸 内病原菌を抑える能力をもつことで知ら れている。一方、屋内飼育の子ブタでは、 腸内微生物叢に占めるファーミキューテス 細菌は 7 割に届かず、隔離条件の子ブタ では、かろうじて 5 割を超えるにとどまっ た。こうした清潔な環境で育った子ブタで は、乳酸桿菌科の細菌の割合も大幅に低 かった。

Kelly らは、腸内微生物の違いが子ブ 夕の免疫系と関連する遺伝子の発現に影
響していることも発見した。隔離環境で 育った子ブタが炎症性免疫応答やコレス テロール合成に関与する遺伝子を多く発 現していたのに対して、屋外育ちの子ブタ は、感染と戦う $T$ 細胞に関係する遺伝子 を発現していた。

レディング大学（英国）の食物微生物 学者である Glenn Gibson によれば、こ れまでの研究からは、免疫応答が腸内の 生物と関係していることが示唆されている という。「今回は、遺伝子発現の応答を免 疫応答と結び付けることによって、研究が 一歩前進しました」とGibson は語る。し かし、この研究で使ったのは子ブタであり、 結果か人間に当てはまるかどうかはよくわ からない、ともいう。

王立リバプール大学病院（英国）の胃 腸病専門医である Jonathan Rhodes は、 「クローン病」という消化管の慢性炎症 の患者にも、清潔な子ブタと同じように ファーミキューテス細菌が少ないことを 指摘している。しかし、クローン病患者 では、屋外飼育の子ブ夕と同様、細菌の 多様性も全体的に低くなっており、今回 の研究成果から人間の病気を直接推測す ることはできないのではないか、と付け 加えている。

しかし、Kellyは、人間とブタは臟器の サイズが同程度であり、腸内にみられる 微生物も似ているので、こうした研究では ブタがモデル動物として優れていると主張 している。(小林盛方 訳)

1. I. E. Mulder et al. BMCBiol. 7, 79; 2009 